\title{
Algae in urban water bodies - control of growth and use as a biomass
}

\author{
Antonina Kalinichenko ${ }^{1, *}$, Pavlo Pisarenko ${ }^{2}$, and Maksym Kulyk ${ }^{2}$ \\ ${ }^{1}$ University of Opole, Dmowskiego str., 7-9, Opole, 45-365, Poland \\ ${ }^{2}$ Poltava State Agrarian Academy, Skovorody Str., 1/3, Poltava, 36003, Ukraine
}

\begin{abstract}
Enhancing the ecology security of Ukraine and other developing countries is predetermined by the environmental problems of cities. It prompts studies on the contamination of city's and adjacent water bodies. The control of blue-green algae distribution and the use of its biomass for production of the biofuels, energy, oils, medicine, etc. is one of the contributing factors to the well-balanced development of infrastructure of cities. The intensity of the processes of eutrophication and the species composition of the algae, which cause algal blooming, was investigated based on data of the Vorskla River in Poltava city (Ukraine). Relevant methods, statistical data of Ukrainian Environmental Service, personal observations, laboratory analysis and analytical studies were applied for the study. The comparative estimation of influence of separate biogenic and chemical substances on eutrophication processes was carried out. The approaches for prevention of processes of water bloom have been presented. The mechanism of using the species composition of algae as an indicator of the state of eutrophication processes was studied.
\end{abstract}

\section{Introduction}

At present, due to the trend of urban population growth and the intensive development of industrial production, the amount of sewage is increasing. This factor leads to an increase in the concentration of contaminants, which causes the contamination of city's and adjacent water bodies, rivers and groundwater $[1,2]$. It provokes the violent reproduction of some algae, which leads to natural water bodies blooming. As a result, oxygen, which is detrimental to fish and the other inhabitants of the water bodies, disappears. In addition, due to the lack of oxygen and a decrease in the speed of river flow, favorable conditions for the development of blue-green algae are ensured; it results in algal bloom. The ideal environment for the blue-green algae is the aqueous media, well-heated by the sun and rich in phosphorus and nitrogen, because of the large amount of organic matter contained in wastewater and rainwater in the soil. The negative consequence of algal bloom is their excessive accumulation, dying, decomposition with the intense absorption of oxygen from the water, which causes breathless of the water bodies, and leads to the death of water fauna [3]. It causes a shift in the ecological balance in the area of organic substances accumulation, the secondary pollution of water bodies and the deterioration of the natural waters

\footnotetext{
* Corresponding author: akalinichenko@uni.opole.pl
} 
quality. Therefore, the study on the features of algae pollution in water bodies, and the ways to eliminate them is of vital importance.

\section{Literature review}

Currently, there are from hundreds of thousands to tens of millions of different algae types; some of them form colonies. At present, it has been determined that microalgae grow spontaneously in the areas where there is water and sunlight. The optimal growth and development of many species of algae is within the temperature range of $20-27^{\circ} \mathrm{C}[4,5]$.

Daroch M., Brentner L.B., Eckelman M.J. [6, 7] found that the research on obtaining additional raw material for biofuel production is oriented on photosynthetic green algae and diatom algae, because the lipids they produce can be converted into biofuels by applying a combined cycle. Titlyanov E.A. and Titlyanova T.V. highlighted the current state in the area of growing global seaweed, the submitted methodological approaches and the basic methods of algae cultivation. The negative influence of large-tonnage monoculture of sea algae on natural benthic biocenoses is underscored [8].

Some experimental results enabled the production of 13,000 liters of ethanol per hectare from algae, with some of them indicating that much higher yields can be achieved [9].

The elimination and dehydration of algae requires a lot of energy. During re-verification (the process of producing biodiesel from algae), algae are first separated from water by centrifugation or filtration, and then dry using solar energy. Subsequently, fat lipids are removed and converted by reaction with alcohol (eg, ethanol or methanol) into biodiesel and glycerin [10]. Schenk P.M. determined that the potential use of algae residues after conversion to biodiesel is the production of feed for animals or the production of methane. Glycerin is a common product of biodiesel processing and can replace glycerol, made from petroleum. Glycerin is useful in cosmetics, food, oral care, tobacco, synthetic polymer production, and synthetic resins [11]. On the other hand, microalgae, as opposed to most of the higher plants, lack heavy load-bearing structures and anchor bodies, that is, rolls that create certain technical constraints on their assembly. The real advantage of microalgae over plants depends on their metabolic flexibility, which makes modification of their biochemical pathways (eg protein, carbohydrate or oil synthesis) and cellular composition possible. Algae-based biofuels have enormous market potential, can eliminate the import of fossil fuels from other countries (hence the dependence of the country), and is one of the new, sustainable technologies that can count on increasing political and consumer support [12].

At the same time, as it was noted by the authors [10,13,14], one of two major types of large-scale algae culture systems, open ponds and rivers are peculiar for the low productivity of algae in comparison with photobioreactors. The joint production of algae of some of these products, along with biofuels, can make the process economically viable, less dependent on imports and fossil fuels; at the local level, it is sufficient and is expected to create new jobs that will have a positive effect on overall sustainability [15].

The purpose of the study - analyze the factors causing eutrophication of water bodies on the basis of research data of the Vorskla River basin in the city of Poltava; establish the species composition of algae, which is the causative agent of water blooming; identify the most effective measures to control this negative phenomenon; present the possibilities of using biomass of algae.

\section{Research methods}

The specificity of the studied subject caused the need for the integrated use of methods: field and laboratory studies, a statistical analysis of observations on the elements of the 
chemical composition of water, modern technologies for the environmental assessment of water quality, mathematical calculation methods, a theoretical analysis and a generalization of the obtained results. For 6 years studies were carried out on the Vorskla River, which flows through the city of Poltava (Ukraine), and is an influx of the Dnipro River. The research was conducted on various parts of the Vorskla River during the spring-summer period of 2010-2016. The analysis applied methodologies, statistical data of the environmental services of Ukraine, personal observations, analyses and analytical studies [16-20].

A determination of the content of substances in the water was carried out by applying standard methods. Color, odor, sediment, turbidity, transparency and taste were determined through general methods for determination of organoleptic parameters. The principle of the determination of nitrates is based on the reaction of phenol disulfonic acid. The dry residue was determined by gravimetric detection of soluble substances. The method for determining the content of chlorides is based on their titrimetric precipitation in a neutral medium with silver nitrate in the presence of potassium chromate as an indicator. The determination of sulfates is based on their precipitation in an acidic medium with barium chloride. Soluble oxygen was determined by the Winkler method. The method of determining the general stiffness is based on the formation of a strong complex communication at $\mathrm{pH} \mathrm{10,0}$ for calcium and magnesium ions from $\mathrm{Na}_{2}$ EDTA.

The number of algae was determined by direct counting in the Goryaev chamber. Selected specimens were studied under a microscope in their living state. Sometimes, observations were conducted over a longer period of time, with the preservation of living material in the northern window of the laboratory and re-sampling in the water bodies during the blooming.

A study of the samples was performed with "Studar" and "Laboval" light microscopes using immersion optics. The size of organisms was measured by a plate-like 7X eyepiecemicrometer. The paper presents the arithmetic mean values of the number of cells in 1 liter (cells/L). The calculation of blue-green algae was carried out with the help of a FuchsRosenthal camera.

Water samples were modified by the introduction of various chemicals, in particular, with aluminum sulfate, together with blue vitriol, potassium permanganate, barium chloride, silver nitrate, magnesia blend, molybdenum fluid, iron chelate and liquid chlorine.

Collecting and studying the plankton of the Vorskla River was carried out using the "plankton grid". A determination of the content of nitrogen and phosphorus in the water was carried out with heteropoly complexes using extraction and sorption separation.

\section{Research results and their discussion}

\section{Types of algae, which cause algal bloom in the Vorskla River.}

The following types of algae dominate the waters of the Vorskla River: dinophytic, diatomaceous, golden, yellow-green, green and blue-green algae. In the summer, the Vorskla River is dominated by blue-green algae. Three species are particularly active at this time of year: Microcystis flos-aquae, Anabaena los-aquae, Aphanizomenon flos-aquae. These species can be vegetated together, but more often one of them multiplies intensively under the favorable conditions and in the short term reaches enormous amounts, that is, the water body begins to bloom. Microcystis flos-aquae is found in the river in the form of colonies and at a water temperature of $20-25^{\circ} \mathrm{C}, \mathrm{pH} 6.8$, the number of algae was $4,0 \cdot 10^{6}$ cells $/ \mathrm{L}$.

Blue-green algae are the dominant components of summer plankton, and in the spring and autumn in the Vorskla River, they strongly prevail over all other diatomaceous organisms, represented mainly by four colonial species. The most notable of these is Asterionella formosa Hassall, the number of which is $1,4 \cdot 10^{6}$ cells/L in the Vorskla River. Another very common plankton species is diatoms, that is, Melosira islandica $\left(4,8 \cdot 10^{6}\right.$ cells/L). The third 
colonial diatom of our planktons is Tabellaria fenestrata, its number amounts to $3,1 \cdot 10^{6}$ cells/L. In the samples of river plankton collected in the spring or autumn, especially on sunny days, many golden algae of two species - Synura uvella Ehr. $\left(1,9 \cdot 10^{6}\right.$ cells/L) and Dinobryon divergens $\left(2,4 \cdot 10^{6}\right.$ cells/L) were found. These are colonial organisms.

The total number of species of plant organisms belonging to the pyridine group (dinophyta algae) in the samples was $6.1 \cdot 10^{6}$ cells/L. In contaminated water bodies with stagnant rotting water, in the coastal zone of the Vorskla River, one can find mobile, single-cell cryptophyte algae. The most common of these is Cryptomonasplatyurus $\left(4,8 \cdot 10^{6}\right.$ cells/ $\left.\mathrm{L}\right)$.

In the summer, the bright green color of the river water is painted by Euglena, which gives name to the whole class of algae. Therefore, in our samples, the total their number was $3,2 \cdot 10^{6}$ cells $/ \mathrm{L}$.

The typical representative of the genus Chlamydomonas in our flora is the Chlamydomonas reinhardtii. At a water temperature of $20-25^{\circ} \mathrm{C}$ and a $\mathrm{pH}$ of 6,8 their number was 1,3 $\cdot 10^{5}$ cells/L.

The genus Gonium is presented in the water bodies with a view of the Gonium pectorale. At a water temperature of $26^{\circ} \mathrm{C}, \mathrm{pH} 6,8$, the number of this algae species was $4,0 \cdot 10^{6}$ cells/L.

Volvox is the most commonly found in forms of spherical colonies. At a water temperature of $20-25^{\circ} \mathrm{C}, \mathrm{pH} 6.8$, the number of this species of algae was $8,1 \cdot 10^{6} \mathrm{cells} / \mathrm{L}$.

Chlorococcales algae are often found in the water bodies of the area. Particularly widespread types of genus are Chlorella, Scenedesmus, Crucigenia tetrapedia, Pediastrum, Hydrodictyon. At a water temperature of $20-25^{\circ} \mathrm{C}, \mathrm{pH} 6,8$, the Chlorella content in the Vorskla river was $6,8 \cdot 10^{6}$ cells/L. Hydrodictyon (water net) is fairly called a giant among green Chlorococcales algae. The size of these algae coenobia sometimes reaches $1 \mathrm{~m}$, and its width is about $8 \mathrm{~cm}$. In the water samples from the Vorskla River, the number of this species of algae was $2,0 \cdot 10^{6}$ cells/L.

Typically, algae blooming causes multicell grouping of algae, but there are species that develop in the form of a pure "monoculture". In this case, one can assume that the biotic factor plays a decisive role in the emergence of algal bloom, and the corresponding species can be considered as potential producers of physiologically active substances. Species such as Pandorina torim and Chlamydomonas noctigama can cause algal bloom both in monoculture and in combination with other types of algae. At the same time, the composition of groups that cause algal bloom may remain stable for several years.

Eutrophication processes and their regulation (exemplified by the Vorskla River). The outcomes of the water studies conducted in various parts of the Vorskla River as well as the city and surrounding areas, show a direct correlation between the content of nitrogen and phosphorus in water and the development of algae. Therefore, the higher the content of nitrogen and phosphorus in the water, the more massive is the development of algae, which, accordingly, enhances the eutrophication process. The research results indicate that the concentration of biogenic elements and their mode depend on the intensity of biological and biochemical processes in the water bodies, and on the amount of nutrients entering the water bodies with sewage and surface runoff at the catchment area (Table 1). In our studies, the water indicators in the Vorskla River were taken for a control; they were selected in the village of Petrivka (the outskirts of the city), since this place does not have a significant anthropogenic impact. On Sakko Street, Poltava (part of a suburb) water pollution indicators have somewhat increased. In the area of the Southern railway station (urban area) there is the largest pollution of the river by all indicators, in particular, the content of nitrogen, phosphorus and the amount of algae that has significant impact on the eutrophication process. This is due to the presence of a residential area in the immediate proximity of the river, as well as the Southern Railway Station, urban roads and sewage pipes, the drain from which enters the river. 
Table 1. The content of substances in different areas of the Vorskla River (on average for the springsummer period, 2010-2016).

\begin{tabular}{|c|c|c|c|c|}
\hline \multirow{2}{*}{ Indexes } & \multicolumn{4}{|c|}{ Measurement points } \\
\hline & surrounding area & suburbs & urban area & city flow out area \\
\hline Odor, scores & \begin{tabular}{|l|}
1 \\
\end{tabular} & 1 & 1 & 1 \\
\hline Smell, scores - at $20^{\circ} \mathrm{C}$ & 2 & 2 & 2 & 2 \\
\hline Colors, degrees & 40,9 & 40,3 & 41,3 & 39,9 \\
\hline Turbidity, scores & 3,0 & 3,2 & 3,6 & 3,7 \\
\hline Sediment & Sandy, grey & Sandy, grey & Sandy, grey & Sandy, grey \\
\hline Transparency, cm & 23 & 27 & 28 & 27 \\
\hline $\mathrm{pH}$ & 7,5 & 7,5 & 7,2 & 7,8 \\
\hline Nitrates, $\mathrm{mg} / \mathrm{dm}^{3}$ & 28,0 & 27,6 & 28,3 & 27,3 \\
\hline Water hardness, mmol/L & 4,45 & 4,65 & 4,50 & 3,50 \\
\hline Dry residue, $\mathrm{mg} / \mathrm{dm}^{3}$ & 873 & 853 & 945 & 796 \\
\hline Chlorides, $\mathrm{mg} / \mathrm{dm}^{3}$ & 59,6 & 68,7 & 71,1 & 57,3 \\
\hline Sulphates, $\mathrm{mg} / \mathrm{dm}^{3}$ & 243 & 246 & 251 & 258 \\
\hline Polyphosphates, $\mathrm{mg} / \mathrm{dm}^{3}$ & 3,1 & 3,4 & 3,3 & 3,3 \\
\hline Phenols, $\mathrm{mg} / \mathrm{dm}^{3}$ & 0,001 & 0,001 & 0,001 & 0,001 \\
\hline Petroleum products, $\mathrm{mg} / \mathrm{dm}^{3}$ & 0,0093 & 0,096 & 0,098 & 0,1 \\
\hline Oxygen saturation, $\%$ & 7,6 & 7,63 & 7,8 & 7,98 \\
\hline Nitrogen, mg/L & 0,3 & 0,23 & 0,31 & 0,25 \\
\hline Phosphorus, mg/L & 0,028 & 0,026 & 0,029 & 0,02 \\
\hline Number of algae, cells/L & $3,9 \cdot 10^{9}$ & $4,15 \cdot 10^{9}$ & $4,25 \cdot 10^{9}$ & $3,51 \cdot 10^{9}$ \\
\hline
\end{tabular}

Source: author's research

Measures to combat water eutrophication (exemplified by the Vorskla River). In order to prevent water bodies eutrophication, taking a set of water protection measures is recommended, which includes the creation of terrestrial and aquatic vegetation around the water bodies. Measures for the prevention of various water bodies eutrophication also include restrictions on the territory of the catchment of water bodies for the development of livestock farms, the replacement of agricultural machinery (use of granulated fertilizers, increasing the depth of their penetration into the soil, adherence to the timing of their introduction into the soil) and the implementation of measures to protect the soil from erosion. Worthy of mention are water conservation measures such as the stoppage of wastewater discharge or the removal of water beyond the boundaries of water bodies; the construction of buffer reservoirs and pre-reservoirs that do not allow wastewater to reach the bases of the water bodies; improvement of sewage treatment, phosphorus binding and sedimentation in water bodies, use of artificial aeration of water bodies with the help of air or oxygen, discharge from the lakes and rivers of the enriched nutrients of the natural water layer; the use of algicides to suppress the development of algae and, finally, the removal of excess organic matter from the water bodies. The prevention of bloom also lies in preventing contamination of water bodies by the biologically decomposing organic substances and biogenic elements.

The biological methods of struggle against bloom are creating artificial surfaces of obesity in the zone of water receipt in the water bodies for the intensification of biological selfpurification. Ensuring conditions for the development of higher aquatic vegetation, which is a consumer of nutrients and the use of algae antagonists is also practical.

Physical methods for combating bloom are artificial turbidity of water with clay, aeration, the use of devices for the removal of algae.

To determine the effects of various chemicals (aluminum sulfate with copper sulfate, 
potassium permanganate, barium chloride, silver nitrate, magnesia mixture, molybdenum liquid, iron chelate and chlorine (liquid)), they were added to a sample of river water. All of the listed chemicals had an inhibitory effect on the development of algae - its number was significantly reduced compared to baseline data (Table 2).

Table 2. Dependence of the number of blue-green algae on the effects of various chemicals.

\begin{tabular}{|l|c|c|}
\hline \multirow{2}{*}{ Chemical substances } & \multicolumn{2}{|c|}{ Number of blue-green algae, cells/L } \\
\cline { 2 - 3 } & $\begin{array}{c}\text { At the beginning of } \\
\text { the experiment }\end{array}$ & $\begin{array}{c}\text { At the end of } \\
\text { the experiment }\end{array}$ \\
\hline $\begin{array}{l}\text { Aluminum sulfate together with } \\
\text { copper sulfate } \mathrm{Al}_{2}\left(\mathrm{SO}_{4}\right)_{3} \cdot \mathrm{CuSO}_{4}\end{array}$ & $3,4 \cdot 10^{6}$ & $2,5 \cdot 10^{6}$ \\
\hline Potassium permanganate $\mathrm{KMnO}_{4}$ & $3,4 \cdot 10^{6}$ & $0,2 \cdot 10^{6}$ \\
\hline Barium chloride $\mathrm{BaCI}_{2}$ & $3,4 \cdot 10^{6}$ & $2,0 \cdot 10^{6}$ \\
\hline Silver nitrate $\mathrm{AgNO}_{3}$ & $3,4 \cdot 10^{6}$ & $1,0 \cdot 10^{6}$ \\
\hline Magnesia mixture & $3,4 \cdot 10^{6}$ & $0,4 \cdot 10^{6}$ \\
\hline Molybdenum liquid & $3,4 \cdot 10^{6}$ & $0,3 \cdot 10^{6}$ \\
\hline Iron chelate & $3,4 \cdot 10^{6}$ & $0,6 \cdot 10^{6}$ \\
\hline Chlorine (liquid) & $3,4 \cdot 10^{6}$ & $0,5 \cdot 10^{6}$ \\
\hline
\end{tabular}

Source: author's research

The most effective result was obtained with the use of potassium permanganate $\left(0,2 \cdot 10^{6}\right.$ cells $/ \mathrm{L})$, molybdenum liquid $\left(0,3 \cdot 10^{6}\right.$ cells/L), magnesia mixture $\left(0,4 \cdot 10^{6}\right.$ cells/L), chlorine $\left(0,5 \cdot 10^{6} \mathrm{cells} / \mathrm{L}\right)$ and iron chelate $\left(0,6 \cdot 10^{6} \mathrm{cells} / \mathrm{L}\right)$. Somewhat worse results were achieved with the use of silver nitrate $\left(1,0 \cdot 10^{6}\right.$ cells $\left./ \mathrm{L}\right)$ and barium chloride $\left(2,0 \cdot 10^{6}\right.$ cells $\left./ \mathrm{L}\right)$. The largest number of blue-green algae remained under the influence of the aluminum sulfate on them.

\section{Use of algae to get an additional product.}

In the case of significant algae multiplication, use of their phytomass for biofuel production is recommended. In this case, animal feed supplement, bio fertilizer for lawn grasses and filling for pharmacological preparations can be made from the waste (Fig. 1-2).

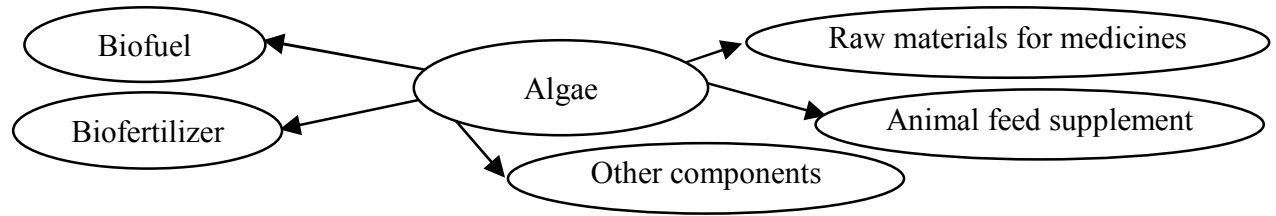

Fig. 1. Scheme of algae use. Sourse: author's research based on $[15,17,21]$.

Possible biofuels from algae include the production of biodiesel, bioethanol, biological oils, biogas, biohydrogen and electricity. At that time, such alternatives as food production are important. Algae are practicing the manufacture of neutral drugs or pharmaceuticals, feed for livestock and aquaculture. In addition, non-food compounds can be used for the chemical industry, cosmetics, as organic fertilizers and an alternative source of fiber for the paper industry. The production of biodiesel from algae oil has been most widespread, since algae can contain potentially more than $80 \%$ of the total number of lipids (although, for example, rape plants contain about $6 \%$ lipids). Under normal conditions of seaweed growth, the concentration of lipids will be lower $(<40 \%)$, their concentration increases under stress conditions. Under such conditions, biomass production is not optimal, however, the nonlipid portion of biomass that can be used as a source for common products.

Along with this, it has been determined that algae of the genus Botryococcus do not produce the abovementioned lipids, but have a longer chain carbohydrate compounds that can be converted into biofuels through a process similar to that for conventional fuel pro- 
duction. Botryococcus is a kind of freshwater nature, but it can also grow in saltwater and can produce certain carotenoids [22].

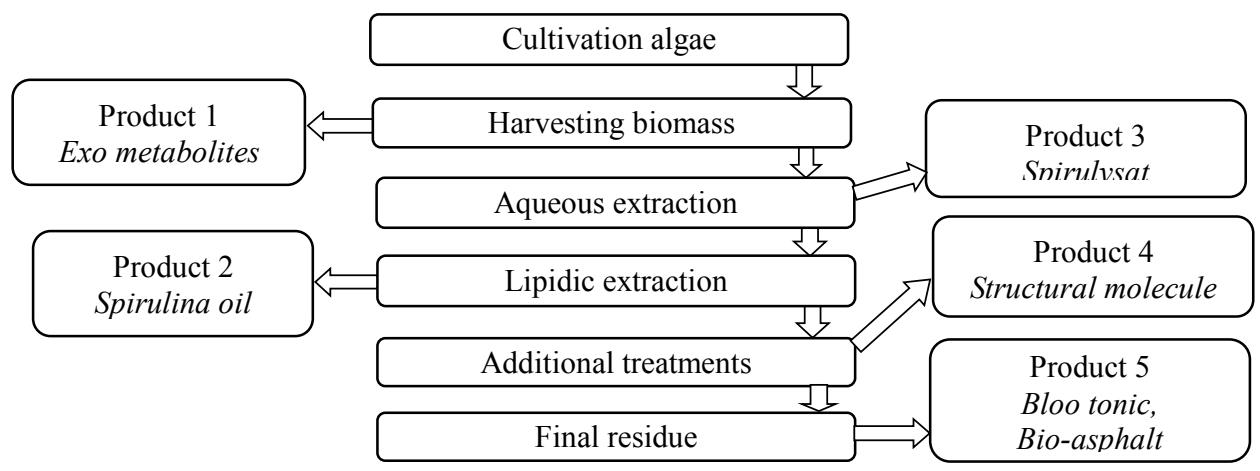

Fig. 2. The scheme of by-products production from algae. Sourse: author's study research on [21].

Ethanol is usually made of starchy raw materials; some algae contain more than $50 \%$ starch. Algae cell walls consist of polysaccharides that can be used as a raw material in a process similar to that of cellulose ethanol. The additional advantage lies in the fact that algae rarely contain lignin and their polysaccharides are generally more easily broken up than woody biomass. Potentially, common products can be produced from noncarbohydrate algae biomass. Anaerobic digestion converts organic material into biogas, which contains about $60-70 \%$ biomethane, and the rest is mainly $\mathrm{CO}_{2}[23,24]$. The main advantage of anaerobic fermentation is the fact that this process can use biomass moisture, reducing the need for drying. Another advantage is that the nutrients contained in the converted biomass can be recovered from the liquid and solid phase.

\section{Conclusions}

1. The main sources of anthropogenic pollution of the water bodies are organized discharges of inadequately treated waters from the treatment facilities of different enterprises, and unorganized discharges, that is, the surface runoff from agricultural lands and urbanized areas.

2. Water bodies in urban areas have increased turbidity of water in comparison with other territories, dry residue and chemicals (chlorides, sulphates, polyphosphates, petroleum products, nitrogen and phosphorus), but have reduced $\mathrm{pH}$ and water hardness. This greatly affects the increase in the algae number.

3. A decisive role in the emergence of algal bloom is played by a biotic factor, and the corresponding species of algae can be considered as potential producers of physiologically active substances. The composition of the groups that cause the water blooming can remain stable for several years.

4. The use of chemical methods for controlling the algae blooming consists in the treatment of water bodies by special chemicals that reduce the amount of algae. It has been established that the multiplication of blue-green algae can be controlled by two main means: by chemicals that have a direct impact on blue-green algae, and by reducing the phosphate ion $\left(\mathrm{PO}_{4}^{3-}\right)$ in water, which ultimately results in a decrease in the number of blue-green algae.

5. The possibility of using algae for the production of by-products for pharmacology, the production of animal feed supplements, bio-fertilizers and biofuels has been identified for the situation then water bodies have a high level algae blooming. 


\section{Reference}

1. C.M. Palmer, Annal. NY Acad. of Scien 108(2), 389-395, DOI: 10.1111/j.17496632.1963.tb13393.x (1963)

2. N.S. Fisher, C.F. Wurster, Environ Conserv, 1(03), 189-190, DOI 10.1017/S0376892900004550 (1971)

3. N. Munir, A. Imtiaz, N. Sharif, S. Naz, J Anim \& Plant Scien 25(2), 545-548 (2015)

4. X. Wang, K.W. Tang, Y. Wang, W.O. Smith, Aquat Biol 9, 239-249 (2010)

5. J.J. Bolton, K. Luning, J Mar Biol 66: 89-94, DOI: 10.1007/BF00397259 (1982)

6. M. Daroch, S. Genga, G. Wang, Appl Energy 102, 1371-1381, DOI: 10.1016/j.apenergy.2012.07.031 (2013)

7. L.B. Brentner, M.J. Eckelman, and Zimmerman, Environ. Sc.\& Techn. 45(16), 7060-7, DOI:10.1021/es2006995 (2011)

8. E.A. Titlyanov, T.V. Titlyanova, Russian J Mar Biol. 36(4), 227-242, DOI: 10.1134/S1063074010040012 (2010)

9. L. Brennan, P. Owende, Renew and Sustain En Rev 14, 557-577, DOI: 10.1016/j.rser.2009.10.009 (2010)

10. Y. Chisti, Biotechn Adv 25, 294-306, DOI: 10.1016/j.biotechadv.2007.02.001 (2007)

11. P.M. Schenk, S.R. Thomas-Hall, E. Stephens et al., BioEn Res 1, 20-43, DOI: 10.1007/s12155-008-9008-8 (2008)

12. M.R. Tredici, Biofuels 1, 143-62, DOI: 10.4155/bfs.09.10 (2010)

13. K.L. Terry, L.P. Raymond, Enzyme Microb Techn 7, 474-87, DOI: 10.1016/01410229(85)90148-6 (1985)

14. A.P. Carvalho, L.A. Meireles, F.X. Malcata, Biotech Prog 22, 1490-506, DOI: 10.1021/bp060065r (2006)

15. T.M. Mata, A.A. Martins, N.S. Caetano, Renew and Sustain En Rev 14(1), 217-32, 10.1016/j.rser.2009.07.020 (2010)

16. B. Włodarczyk, P.P.Włodarczyk, A. Kalinichenko, E3S Web Conf 19, 01025, DOI: 10.1051/e3sconf/20171901025 (2017)

17. P.A. Roger, R. Jimenez, S. Santiago-Ardales. IRRI Res Paper Ser 150, 1-19, http://horizon.documentation.ird.fr/exl-doc/pleins_textes/pleins_textes_6/b_fdi_3334/36367.pdf (1992)

18. T. Varunan, P. Shanmugam, J Gr Lakes Res. 43(1), 32-49, DOI: 10.1016/j.jglr.2016.1 1.001 (2017)

19. Seaweeds, sea grasses and products of their processing. Acceptance rules and sampling methods. (Moskva: Standartinform, 2011), http://docs.cntd.ru/document/1200082878

20. Ministry of Ecology and natural resources of Ukraine, https://menr.gov.ua/en/ (2011)

21. J.M. Pommet, ECO innovations from biomass, Papenburg, https://www.3n.info/media/4_Downloads/pdf_Biooeknm_Algen_Stmmtsch_Pommet.pdf(2015)

22. A Banerjee, R. Sharma, Y. Chisti, U.C. Banerjee, Crit Rev. Biotechn. 22, 245-79, DOI: 10.1080/07388550290789513 (2002)

23. A. Kalinichenko, V. Havrysh, V. Perebyynis, ECE S 23(3), 387-400, DOI: 10.1515/eces-2016-0027 (2016)

24. A. Kalinichenko, V. Havrysh, V. Perebyynis, Appl Ecol Env Res, 15(4), 969-985. DOI: 10.15666/aeer/1504_969985(2017) 